Article

\title{
Catalytic Conversion of Palm Oil to Bio-Hydrogenated Diesel over Novel N-Doped Activated Carbon Supported Pt Nanoparticles
}

\author{
Wei Jin ${ }^{1}$, Laura Pastor-Pérez ${ }^{1,2}$, Juan J. Villora-Pico ${ }^{2}$, Mercedes M. Pastor-Blas ${ }^{2}$, \\ Antonio Sepúlveda-Escribano ${ }^{2}$, Sai Gu ${ }^{1}$, Nikolaos D. Charisiou ${ }^{3}$, Kyriakos Papageridis ${ }^{3}$, \\ Maria A. Goula ${ }^{3, *(\mathbb{D})}$ and Tomas R. Reina ${ }^{1, *(\mathbb{D}}$ \\ 1 Chemical \& Process Engineering Department, University of Surrey, Guildford GU2 7XH, UK; \\ w.jin@surrey.ac.uk (W.J.); 1.pastorperez@surrey.ac.uk (L.P.-P.); sai.gu@surrey.ac.uk (S.G.) \\ 2 Laboratorio de Materiales Avanzados, Departamento de Química Inorgánica Instituto Universitario de \\ Materiales de Alicante, Universidad de Alicante, 03690 Alicante, Spain; jjvillora@ua.es (J.J.V.-P.); \\ mercedes.pastor@ua.es (M.M.P.-B.); asepul@ua.es (A.S.-E.) \\ 3 Department of Chemical Engineering, University of Western Macedonia, 50100 Kozani, Greece; \\ ncharis@teiwm.gr (N.D.C.); kpapageridis@teiwm.gr (K.P.) \\ * Correspondence: mgoula@teiwm.gr (M.A.G.); t.ramirezreina@surrey.ac.uk (T.R.R.); \\ Tel.: +44-148-368-6597 (T.R.R.)
}

Received: 12 November 2019; Accepted: 20 December 2019; Published: 26 December 2019

\begin{abstract}
Bio-hydrogenated diesel (BHD), derived from vegetable oil via hydrotreating technology, is a promising alternative transportation fuel to replace nonsustainable petroleum diesel. In this work, a novel Pt-based catalyst supported on N-doped activated carbon prepared from polypyrrole as the nitrogen source $(\mathrm{Pt} / \mathrm{N}-\mathrm{AC})$ was developed and applied in the palm oil deoxygenation process to produce BHD in a fixed bed reactor system. High conversion rates of triglycerides (conversion of TG $>90 \%$ ) and high deoxygenation percentage $\left(\mathrm{DeCO}_{\mathrm{x}} \%=76 \%\right.$ and $\mathrm{HDO} \%=7 \%$ ) were obtained for the palm oil deoxygenation over $\mathrm{Pt} / \mathrm{N}-\mathrm{AC}$ catalyst at optimised reaction conditions: $\mathrm{T}=300{ }^{\circ} \mathrm{C}$, 30 bar of $\mathrm{H}_{2}$, and $\mathrm{LHSV}=1.5 \mathrm{~h}^{-1}$. In addition to the excellent performance, the $\mathrm{Pt} / \mathrm{N}-\mathrm{AC}$ catalyst is highly stable in the deoxygenation reaction, as confirmed by the XRD and TEM analyses of the spent sample. The incorporation of $\mathrm{N}$ atoms in the carbon structure alters the electronic density of the catalyst, favouring the interaction with electrophilic groups such as carbonyls, and thus boosting the $\mathrm{DeCO}_{\mathrm{x}}$ route over the HDO pathway. Overall, this work showcases a promising route to produce added value bio-fuels from bio-compounds using advanced N-doped catalysts.
\end{abstract}

Keywords: deoxygenation; palm oil; bio-hydrogenated diesel; Pt catalyst; N-doped carbon

\section{Introduction}

The utilisation of renewable energy sources has been encouraged in view of economic and environmental considerations such as the energy crisis, rising crude oil price, air pollution and global warming, all of which stem from the dependence on fossil fuels. Biomass resources play the dominant role in the renewable energy portfolio. Statistically, the total primary energy supply from bio-resources constitutes approximately $70 \%$ of all the renewable energy sources in 2016 [1]. Biofuels are the leading renewable solution for the transport sector, in particular for heavy transport such as aviation and shipping. Biofuel production has increased 10 times from 16 billion litres in 2000 to 143 billion litres in 2017 [1]. Biofuel can be produced from organic residues and diverse bio-compounds such as triglycerides. The life cycle of biodiesel is shown in Figure 1. Natural triglycerides originating from vegetable oils and animal fats consist of a glycerol backbone with three fatty acid moieties [2]. 
They possess the potential to produce hydrocarbon fuels considering their simple structure and low degree of functionalization [3]. Typically, two main catalytic reactions could covert triglycerides into biofuel for diesel engines: (1) transesterification with methanol to produce fatty acid methyl esters (FAMEs); (2) catalytic deoxygenation process to produce bio-hydrogenated diesel (BHD), i.e., so-called green diesel. FAMEs, the first generation of biodiesels, is typically used as a component in diesel blending [4]. However, the deteriorated properties of FAMEs, such as limited compatibility with conventional diesel, low thermal and oxidation stability, and possible engine problems arising from the remaining of $\mathrm{C}=\mathrm{C}$ and $\mathrm{C}=\mathrm{O}$ bonds, limits their application in industry. In contrast, $\mathrm{BHD}$ derived from the deoxygenation of vegetable oil or animal fats presents better diesel properties such as high cetane numbers, zero oxygen, and high thermal and oxidation stability [5]. For instance, palm oil, which contains primarily $\mathrm{C}_{16}$ and $\mathrm{C}_{18}$ fatty acids, is a promising feedstock for the production of BHD through the catalytic deoxygenation process. The BHD derived from the deoxygenation of vegetable oil possesses a high cetane number, i.e., ranging from 85 to 99 [6], which is fully compatible with conventional diesel fuel. In the upgrading process, triglycerides are hydrogenated to produce saturated triglycerides [7], and then undergo hydrogenolysis reactions to produce fatty acids and propane gas [8]. Finally, the fatty acid could be subjected to a deoxygenation process to produce BHD. Three major reaction pathways typically occur in the deoxygenation of fatty acids, which include decarbonylation (DeCO), decarboxylation $\left(\mathrm{DeCO}_{2}\right)$ and hydrodeoxygenation $(\mathrm{HDO})$ as pointed out in Figure 1 [9]. Specifically, these three processes consist of (1) DeCO, the elimination of oxygen in the form of $\mathrm{CO}$; (2) $\mathrm{DeCO}_{2}$, the removal of oxygen in the form of $\mathrm{CO}_{2}$, and (3) $\mathrm{HDO}$, the withdrawal of oxygen in the form of $\mathrm{H}_{2} \mathrm{O} . \mathrm{H}_{2}$ consumption for the deoxygenation of fatty acids follows the order $\mathrm{DeCO}_{2}<\mathrm{DeCO}<\mathrm{HDO}$ [10]. N-alkanes produced from the HDO pathway maintain the same carbon number compared to the original fatty acid. In contrast, $\mathrm{DeCO}$ and $\mathrm{DeCO}_{2}$ possess the advantages of consuming reduced or no hydrogen compared to $\mathrm{HDO}$. Hence, $\mathrm{DeCO}$ routes are attractive from an economic standpoint [11,12] considering the high cost of $\mathrm{H}_{2}$ and the problems associated with hydrogen manipulation and transportation.

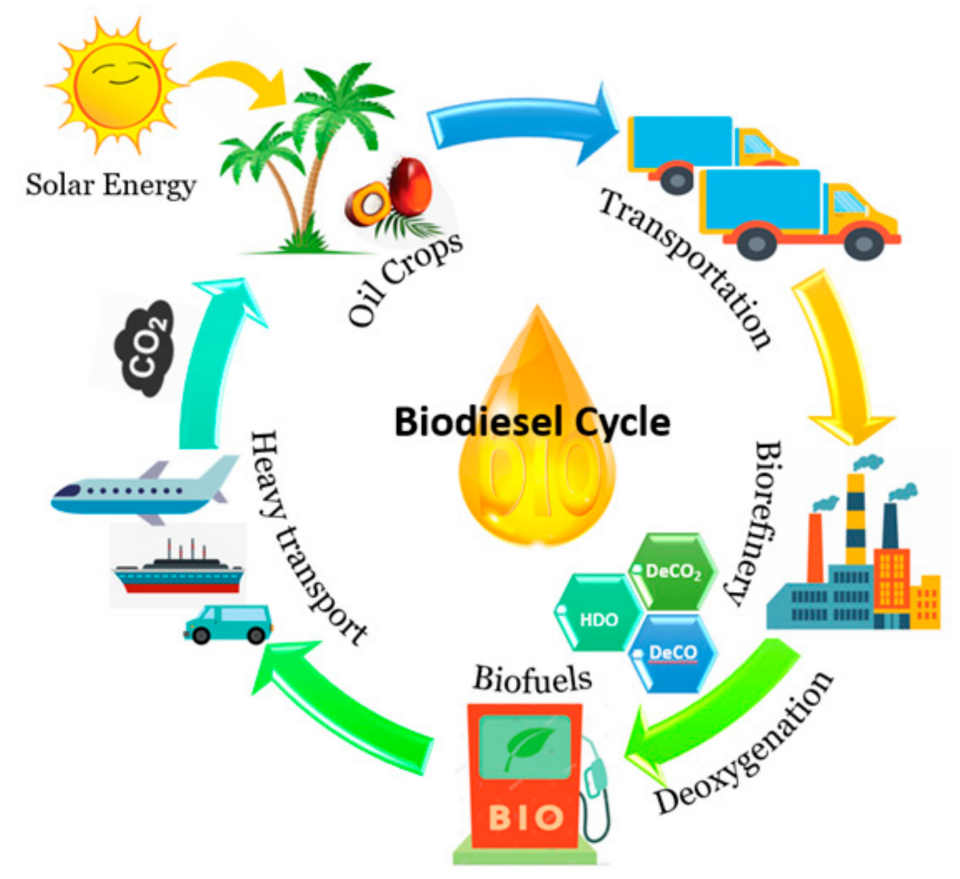

Figure 1. The life cycle of biodiesel.

The nature of the catalyst plays a primary role in the catalytic deoxygenation process. The earliest attempts to deoxygenate fatty acids date back to the year of 1936, which were conducted in a homogenous catalytic reaction system [13]. The heterogeneous catalysed deoxygenation (excluding 
pyrolysis) of vegetable-based feeds scarcely gained attention until the 21st century [14]. Heterogeneous metal catalysts are promising candidates for deoxygenation reactions considering their high reactivity at mild temperatures $\left(<400{ }^{\circ} \mathrm{C}\right)$ and low $\mathrm{H}_{2}$ pressure requirements. Nonnoble catalysts, such as $\mathrm{Ni}$ [10] and Co [3], and noble catalysts such as Pd [15], Pt [16] and Ru [14] have been demonstrated to be sensible choices for the deoxygenation of seed oil, fat oil or model compounds. Snare et al. did a comprehensive investigation about the deoxygenation of fatty acids and their esters over numerous metals (Pd, Pt, Ru, Mo, Ni, Rh, Ir and Os) supported on carbon or metal oxides [14]. Their results indicated that $\mathrm{DeCO}_{2}$ is mostly favoured over $\mathrm{Pd}$ and $\mathrm{Pt}$ metal particles supported on carbon. In view of these results, investigations of fatty acid deoxygenation have been mostly focused on Pd and Pt-based catalysts in recent years [17-21]. Ni-based catalysts are also promising candidates for the deoxygenation of fatty acids, which could achieve comparable results with $\mathrm{Pd}$ and Pt catalysts by increasing their Ni content [22].

Irrespective of the active metal, the nature of the support is the key to ensure successful performance in the upgrading reaction. In this regard, nitrogen-doped carbons (NC) have received increased attention in recent years. It has been reported that the physical and chemical properties can be significantly improved by doping nitrogen into the carbon architecture, making NCs the leading materials in various applications such as supercapacitors, oxygen reduction catalysts and catalyst supports, etc. [23]. In particular, NC materials are widely used as catalyst supports, and perform well in the hydrodeoxygenation (HDO) of bio-phenolic compounds [24,25]. The introduction of $\mathrm{N}$ in the carbon structure modifies the electronic properties of the carbon matrix. More specifically, $\mathrm{N}$ alters the electronic density of the $\mathrm{sp}^{2}$ carbon, thus facilitating $\mathrm{H}_{2}$ activation on metal nano-particles (NPs) by lowering the dissociation energy [26]. It is reported that the nitrogen species in Ni/N-doped carbon black (NCB) greatly promote the reduction of metal oxides and promote the stability of metal particles at ambient atmosphere [27]. The good performance of NC-supported catalysts in the HDO of phenolics inspired us to explore their behaviour in the upgrading of other bio-resources, such as fatty acids. Indeed, very few reports dealing with the application of the NC-supported catalysts in the upgrading of fatty acids through catalytic deoxygenation process can be found in the literature, thus compelling us to investigate the matter [28].

In this study, a $\mathrm{N}$-doped activated carbon supported Pt catalyst (Pt/N-AC) was synthesised and tested in a palm oil deoxygenation process to produce bio-hydrogenated diesel. The effect of the reaction temperature, pressure and space velocity was evaluated to explore the impact of key parameters aiming to optimise the reaction conditions for the upgrading process. The effect of nitrogen in the carbon structure on the catalytic performance of catalyst was illustrated, in which the performance of a reference $\mathrm{Pt} / \mathrm{AC}$ was tested at optimised reaction condition as a contrast experiment. Our study could provide guidance for the selection of a catalyst and for the optimization of the reaction conditions for green diesel production from seed oil and fats.

\section{Experimental}

\subsection{Catalyst Preparation}

For the preparation of the $\mathrm{N}$-doped carbon (N-AC), polypyrrole was synthesised via oxidative polymerization in the presence of a commercial activated carbon (RGC-30). First, $2.4 \mathrm{~g}$ of activated carbon was dispersed in $200 \mathrm{~mL}$ of acetone with an ultrasonic treatment for $30 \mathrm{~min}$. Then, $24 \mathrm{mmol}$ of pyrrole $\left(\mathrm{C}_{4} \mathrm{H}_{5} \mathrm{~N}\right)$ were dissolved in $200 \mathrm{~mL}$ of distilled water, and the solution was added to the $\mathrm{AC}$ dispersion. The mixture was stirred for $30 \mathrm{~min}$, and then $48 \mathrm{mmol}$ of ammonium peroxidisulphate $\left(\left(\mathrm{NH}_{4}\right)_{2} \mathrm{~S}_{2} \mathrm{O}_{8}\right)$, previously dissolved in $200 \mathrm{~mL}$ of distilled water, was added dropwise. The resulting solution was stirred for $4 \mathrm{~h}$ at room temperature. The precipitated formed was filtered, washed with distilled water and dried at $80^{\circ} \mathrm{C}$ for $24 \mathrm{~h}$. The percentage of $\mathrm{N}$ in the synthesised N-AC was 3.3 at.\%, which was derived from N1s core level XPS result. To obtain the final AC, the solid was pyrolysed for $4 \mathrm{~h}$ at $900{ }^{\circ} \mathrm{C}$ under flowing $\mathrm{N}_{2}(50 \mathrm{~mL} / \mathrm{min})$ with a heating rate of $5{ }^{\circ} \mathrm{C} / \mathrm{min}$. 
The $\mathrm{Pt} / \mathrm{AC}$ and $\mathrm{Pt} / \mathrm{N}-\mathrm{AC}$ catalysts were prepared by wet impregnation using chloroplatinic acid hexahydrate $\left(\mathrm{H}_{2} \mathrm{PtCl}_{6} \cdot 6 \mathrm{H}_{2} \mathrm{O}\right)$ as the $\mathrm{Pt}$ precursor. The carbon supports were immersed in aqueous solutions containing the appropriate amount of $\mathrm{H}_{2} \mathrm{PtCl}_{6}$ to obtain $1 \mathrm{wt} . \% \mathrm{Pt}$ loaded. The slurries were stirred for $24 \mathrm{~h}$, and the solvent was gently removed under vacuum at $60{ }^{\circ} \mathrm{C}$. Finally, the metal catalysts (Pt/AC and Pt/N-AC) were dried in an oven at $80^{\circ} \mathrm{C}$ for $24 \mathrm{~h}$. XRD data are included in the supporting info.

\subsection{Catalyst Characterisation}

Powder X-ray diffraction (XRD) patterns of the samples were collected on an X'Pert Pro PANalytical, using $\mathrm{Cu} \mathrm{K} \alpha$ radiation $(40 \mathrm{~mA}, 45 \mathrm{kV})$. The spectra were registered over a $2 \theta$ range between $10-90^{\circ}$, with a step of $0.05^{\circ}$ and a time per step of $160 \mathrm{~s}$.

Transmission Electron Microscopy (TEM) images were taken with a JEOL electron microscope (model JEM-2010) working at $200 \mathrm{kV}$. This was equipped with an INCA Energy TEM 100 analytical system and a SIS MegaView II camera. Samples for analysis were suspended in ethanol and placed on copper grids with a holey-carbon film support.

\subsection{Catalytic Deoxygenation Testing}

Catalytic deoxygenation experiments were carried out in an Autoclave Engineers BTRS high-temperature and high-pressure testing system, equipped with a high-pressure HPLC pump (Series I), followed by metering valves to control the flow rate of the liquid and gas feeding, respectively. A continuous flow, fixed-bed tubular stainless-steel reactor with an internal diameter of $0.7 \mathrm{~cm}$, length of $30 \mathrm{~cm}$ and volume of $12 \mathrm{~mL}$ was used in the experiments. Prior to catalytic testing, a specific amount of catalyst (either $0.12,0.09,0.072,0.06 \mathrm{~g}$ depending on the LHSV used) held in place using quartz wool was reduced in situ under a flow of $100 v / v \%$ of $\mathrm{H}_{2}(50 \mathrm{~mL} / \mathrm{min})$ under atmospheric pressure, at $400{ }^{\circ} \mathrm{C}$, for $2 \mathrm{~h}$. Next, the system was set to the desired reaction temperature under a flow of high purity $\mathrm{N}_{2}\left(100 \mathrm{~mL} / \mathrm{min}\right.$ ) and pressurised with $\mathrm{H}_{2}$ to the desired pressure (controlled by a back pressure regulator). Liquid solutions of the feed i.e., $3 \mathrm{wt} . \%$ of palm oil dissolved in dodecane (solvent) were injected into the system at a rate of $0.1 \mathrm{~mL} / \mathrm{min}$, along with a flow of $\mathrm{H}_{2}$. The fatty acid compositions of the refined palm olein (wt.\%) are listed in Table 1. Palmitic acid, oleic acid and linoleic acid occupy more than $95 \mathrm{wt} . \%$ of the fatty acid composition in palm oil. Liquid and gaseous products were passed through a liquid-gas separator which was placed downstream from the catalyst bed. Liquid products were manually collected for analysis using GC/MS. The effect of reaction temperature, $\mathrm{H}_{2}$ pressure and liquid hourly space velocity (LHSV) were tested under constant $\mathrm{H}_{2} /$ oil ratio, $1000 \mathrm{~cm}^{3} / \mathrm{cm}^{3}$ in deoxygenation of palm oil over $\mathrm{Pt} / \mathrm{N}-\mathrm{AC}$, and the optimised reaction conditions were obtained. To test the reproducibility of the experimental results, the experiments concerning the Pt/ $\mathrm{N}-\mathrm{AC}$ catalyst were repeated three times. From these experiments, 95\% confidence intervals for the mean value were calculated. To explore the effect of $\mathrm{N}$ on the catalytic activity, a contrast test over $\mathrm{Pt} / \mathrm{AC}$ was also conducted. Each test was performed for $6 \mathrm{~h}$ and the liquid products were analysed at $1 \mathrm{~h}$ intervals.

Table 1. Fatty acid composition of the palm oil.

\begin{tabular}{cccc}
\hline Fatty Acid & Structure & Formula & Composition, wt.\% \\
\hline Myristic acid & $\mathrm{C}_{14: 0}$ & $\mathrm{C}_{14} \mathrm{H}_{28} \mathrm{O}_{2}$ & 0.90 \\
Palmitic acid & $\mathrm{C}_{16: 0}$ & $\mathrm{C}_{16} \mathrm{H}_{32} \mathrm{O}_{2}$ & 41.60 \\
Palmitoleic acid & $\mathrm{C}_{16: 1}$ & $\mathrm{C}_{16} \mathrm{H}_{30} \mathrm{O}_{2}$ & 0.70 \\
Stearic acid & $\mathrm{C}_{18: 0}$ & $\mathrm{C}_{18} \mathrm{H}_{36} \mathrm{O}_{2}$ & 2.10 \\
Oleic acid & $\mathrm{C}_{18: 1}$ & $\mathrm{C}_{18} \mathrm{H}_{34} \mathrm{O}_{2}$ & 43.90 \\
Linoleic acid & $\mathrm{C}_{18: 2}$ & $\mathrm{C}_{18} \mathrm{H}_{32} \mathrm{O}_{2}$ & 10.40 \\
Linolenic acid & $\mathrm{C}_{18: 3}$ & $\mathrm{C}_{18} \mathrm{H}_{30} \mathrm{O}_{2}$ & 0.40 \\
\hline
\end{tabular}

* The numbers indicate the number of carbon atoms and the number of double bonds in each of the fatty acids, respectively. 


\subsection{Product Analysis}

The liquid samples were analysed on an Agilent 7890A/5975C Triple-Axis Detector diffusion pump Gas Chromatographer-Mass Spectrometer (GC-MS) (AGILENT, Santa Clara, CA, USA) equipped with an Agilent Multimode inlet. High injection and column temperatures were used to directly analyse triglyceride so as to avoid chemical derivatisation. A split ratio of 25:1 was held and a split flow of $50 \mathrm{~mL} / \mathrm{min}$ was used. The temperature of the inlet was set at $300^{\circ} \mathrm{C}$ for the duration of the analysis and the volume of the samples injected was $1 \mu \mathrm{L}$. The oven temperature program was initially set at $45^{\circ} \mathrm{C}$ for $2 \mathrm{~min}$; it was later increased by $4{ }^{\circ} \mathrm{C} / \mathrm{min}$ to $325^{\circ} \mathrm{C}$, and then to $380^{\circ} \mathrm{C}$ with a ramp of $10^{\circ} \mathrm{C} / \mathrm{min}$. The maximum temperature was maintained for $12.5 \mathrm{~min}$ and the total run time was $90 \mathrm{~min}$. An Agilent $30 \mathrm{~m}$ $\times 320 \mu \mathrm{m} \times 0.1 \mu \mathrm{m} \mathrm{J \& W}$ DB5-HT capillary column (5\% phenyl, 95\% methylpolysiloxane) was employed to achieve chromatographic separation, operated under a constant flow rate mode of $\mathrm{He}(2 \mathrm{~mL} / \mathrm{min})$. The temperature of the ion source, the quadrupole and the MS interface for both instruments were 230, 150 and $330^{\circ} \mathrm{C}$, respectively. The GC/MSD ChemStation software (AGILENT, Santa Clara, CA, USA) was used to identify the species of products. A representative GC chromatograph identifying the product of liquid products is presented in Figure S1.

The conversion of triglycerides (TG), the yield of $\mathrm{C}_{15}-\mathrm{C}_{18}$ products, the HDO percentage and also the decarbonylation and/or decarboxylation $\left(\mathrm{DeCO}_{\mathrm{x}}\right)$ percentage were calculated using Equations (1)-(4), respectively. It should be noted that the relative activity of the DeCO and $\mathrm{DeCO}_{2}$ could not be directly correlated with the amount of produced $\mathrm{CO}$ and $\mathrm{CO}_{2}$, considering that gas phase reactions such as methanation (i.e., $\mathrm{CO}+3 \mathrm{H}_{2} \leftrightarrow \mathrm{CH}_{4}+\mathrm{H}_{2} \mathrm{O}$ and $\mathrm{CO}_{2}+4 \mathrm{H}_{2} \leftrightarrow \mathrm{CH}_{4}+2 \mathrm{H}_{2} \mathrm{O}$ ) and the water-gas shift (WGS) reactions (i.e., $\mathrm{CO}+\mathrm{H}_{2} \mathrm{O} \leftrightarrow \mathrm{CO}_{2}+\mathrm{H}_{2}$ ) could occur under the studied reaction condition $\left(250-350^{\circ} \mathrm{C}\right)$.

$$
\begin{gathered}
\text { Conversion of TG }(\%)=\left(\frac{n_{T G, \text { in }}-n_{T G, \text { out }}}{n_{T G, \text { in }}}\right) \times 100 \\
\text { Yield of } C_{\mathrm{i}}=\left(\frac{n_{\mathrm{Ci}}}{n_{\mathrm{C} 16, \text { in }}+n_{\mathrm{C} 18, \text { in }}}\right) \times 100 \\
\mathrm{HDO}(\%)=\left(\frac{n_{c 16}+n_{\mathrm{C} 18}}{n_{c 16, \text { in }}+n_{\mathrm{C} 18, \text { in }}}\right) \times 100 \\
\operatorname{DeCO}_{\mathrm{x}}(\%)=\left(\frac{n_{c 15}+n_{\mathrm{C} 17}}{n_{c 16, \text { in }}+n_{\mathrm{C} 18, \text { in }}}\right) \times 100
\end{gathered}
$$

$n_{T G, i n}$ : Initial mole of triglycerides; $n_{T G, \text { out }}$ : Detected mole of triglycerides in the products.

$n_{C i}$ : Mole of product alkanes, $i=15$ to 18 .

$n_{C 16, i n}$ : Initial mole of $\mathrm{C}_{16} ; n_{\mathrm{C} 18, i n}$ : Initial mole of $\mathrm{C}_{18}$.

\section{Results \& Discussion}

\subsection{Deoxygenation of Palm Oil}

In our deoxygenation reaction system, the deoxygenation of palm oil was performed under a $\mathrm{H}_{2}$ atmosphere. Even though $\mathrm{DeCO}_{2}$ of fatty acids does not need a supply of $\mathrm{H}_{2}$, the addition of $\mathrm{H}_{2}$ could increase the rate of the deoxygenation reaction [29]. Moreover, it has been demonstrated that the aromatisation reaction can be inhibited to some extent under a $\mathrm{H}_{2}$ atmosphere. The aromatisation reaction is undesirable, considering that aromatics could be the precursors to the formation of coke, which could lead to catalyst deactivation and reactor fouling [30].

Solvent type strongly affects the catalytic performance. A nonpolar organic solvent, dodecane, other than nonsolvent or water was used in our reaction system considering its multiple benefits. On one hand, the occurrence of coupling reactions between the intermediates in a solventless reaction system will decrease the selectivity of desired alkane products [31]. On the other hand, the flow rate 
of palm oil can be controlled well, especially in low feeding mode. Compared with using water as a solvent, the use of a hydrocarbon can omit the separation process of deoxygenated products from water. In addition, the presence of water may block the adsorption of the reactant on the active sites of the catalyst [32].

\subsubsection{Effect of Temperature}

Reaction temperature plays a fundamental role in the palm oil upgrading reaction. The effect of reaction temperature $\left(250-350^{\circ} \mathrm{C}\right)$ in the palm oil deoxygenation process using $\mathrm{Pt} / \mathrm{N}-\mathrm{AC}$ as a catalyst

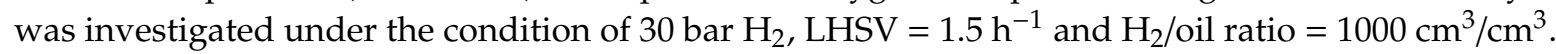
At temperatures lower than $300{ }^{\circ} \mathrm{C}$, the deoxygenation of triglycerides to n-alkanes is incomplete, with the conversion of TG being lower than $70 \%$. Typically, reactants, intermediates and products will be co-existing in the collected liquid under these temperatures [3]. As demonstrated in Figure 2, the highest conversion of triglycerides, i.e., $>90 \%$, was achieved at $300^{\circ} \mathrm{C}$. However, the conversion decreased slightly with the increasing temperature $\left(300-350^{\circ} \mathrm{C}\right)$. It is speculated that a minor sintering of noble metal occurred when the temperature increased to $350^{\circ} \mathrm{C}$, resulting in a slight decrease in TG conversion.

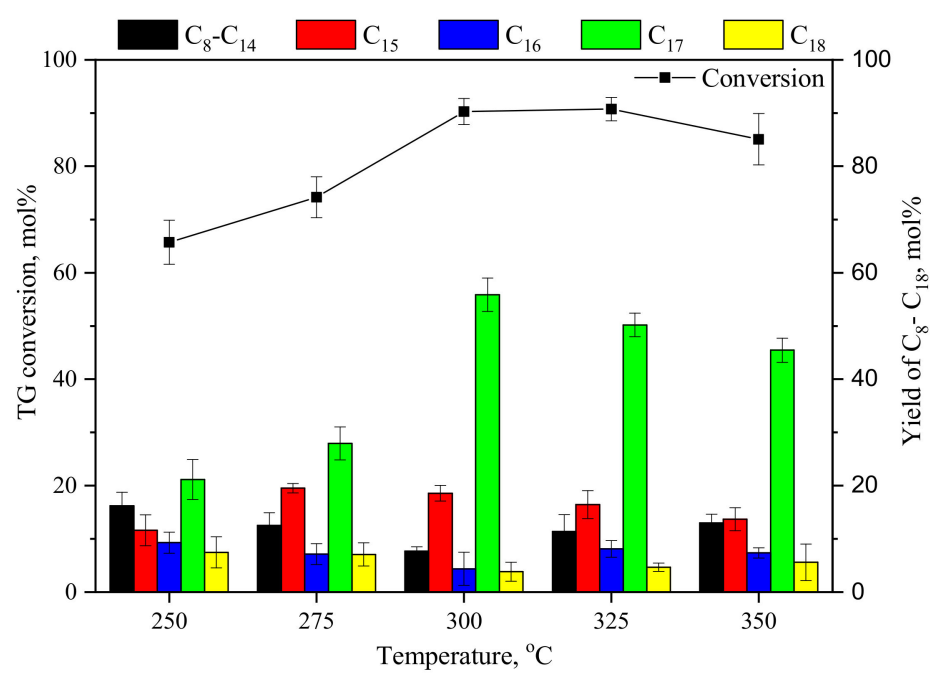

Figure 2. Conversion of triglycerides and yield of $\mathrm{C}_{8}-\mathrm{C}_{18}$ products under different reaction temperatures.

Figure 2 also shows the total yield of $\mathrm{C}_{8}-\mathrm{C}_{18}$ obtained from palm oil deoxygenation at different reaction temperatures. The palm oil used in our study was mainly composed of $C_{16}$ and $C_{18}$ (see Table 1). Thus, the dominant $\mathrm{C}_{17}$ product is likely produced from $\mathrm{C}_{18}$ though the $\mathrm{DeCO}_{\mathrm{x}}$ pathway. For temperatures lower than $300{ }^{\circ} \mathrm{C}$, the total yield of $\mathrm{C}_{8}-\mathrm{C}_{18}$ compounds was relatively low, considering the low conversion of the reactant. However, when the temperature is higher than $300{ }^{\circ} \mathrm{C}$, the cracking of the carbon-Carbon chain was enhanced, resulting in a higher yield of light hydrocarbon compounds $\left(\mathrm{C}_{8}-\mathrm{C}_{14}\right)$. The details about the composition of light hydrocarbon products $\left(C_{8}-C_{14}\right)$ are shown in Table S1. The slight decrease of the total yield of n-alkanes when the temperature was higher than $300^{\circ} \mathrm{C}$ could be attributed to the smooth depletion of TG conversion (Figure 2). This may also have been due to the formation of higher aromatic products, since in most cases, higher temperatures favour the production of larger aromatic compounds in the deoxygenation process [33]. As demonstrated in Equations (3) and (4), $\mathrm{C}_{16}$ and $\mathrm{C}_{18}$ products are produced from the HDO route while $C_{15}$ and $C_{17}$ are from the DeCO $C_{x}$ pathway. The higher yield of $C_{16}$ and $C_{18}$ and lower yield of $C_{15}$ and $\mathrm{C}_{17}$ indicated that higher temperatures favour the $\mathrm{HDO}$ but inhibit the $\mathrm{DeCO}_{\mathrm{x}}$ route $\left(\mathrm{T}>300^{\circ} \mathrm{C}\right)$.

To better understand the deoxygenation behaviour under different reaction temperatures, the contribution of different reaction routes, i.e., $\mathrm{DeCO}_{\mathrm{x}}$ and $\mathrm{HDO}$, are also presented (Figure 3). Overall, the 
$\mathrm{DeCO}_{\mathrm{x}}$ route dominated under all the studied temperatures. The results are consistent with previous studies showing that $\mathrm{DeCO}_{\mathrm{x}}$ was favoured over $\mathrm{HDO}$ for Pt-based catalysts in the deoxygenation of vegetable oil $[3,34]$. It is reported that the selectivity to $\mathrm{DeCO}_{x}$ or $\mathrm{HDO}$ does not depend on the reaction temperature. Instead, the $\mathrm{DeCO}_{x}$ or $\mathrm{HDO}$ pathway is determined by the nature of the catalyst [33]. At $300{ }^{\circ} \mathrm{C}$, the $\mathrm{DeCO}_{x}$ percentage occupies the highest proportion of deoxygenation capacity, whereas the HDO percentage is the lowest. This is advantageous from an economic perspective, given that DeCO $\mathrm{x}_{x}$ consumes much less $\mathrm{H}_{2}$ than $\mathrm{HDO}$. Overall, $300{ }^{\circ} \mathrm{C}$ is the optimal reaction temperature for deoxygenation of palm oil over $\mathrm{Pt} / \mathrm{N}-\mathrm{AC}$ catalyst considering the highest TG conversion and the total yield of $\mathrm{C}_{8-18}$. At this temperature the $\mathrm{DeCO}_{\mathrm{x}}$ route is favoured over the $\mathrm{HDO}$ pathway.

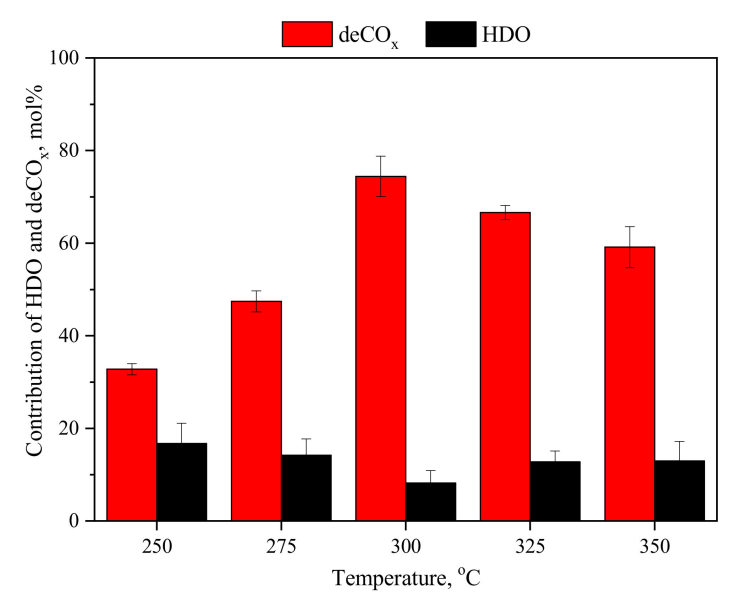

Figure 3. Contribution of $\mathrm{HDO}$ and $\mathrm{DeCO}_{\mathrm{x}}$ under different reaction temperatures.

\subsubsection{Effect of $\mathrm{H}_{2}$ Pressure}

The effect of $\mathrm{H}_{2}$ partial pressure in the deoxygenation of palm oil was investigated by varying $\mathrm{H}_{2}$ pressure from 20 to 30 bar. As depicted in Figure 4, the raise of the $\mathrm{H}_{2}$ pressure from 20 to 30 bar monotonously increased the TG conversion. Interestingly, as shown in Figure 5, higher $\mathrm{H}_{2}$ pressure favours the DeCO $\mathrm{x}_{x}$ pathway but inhibits the $\mathrm{HDO}$ pathway. Accordingly, lower $\mathrm{C}_{16}$ and $\mathrm{C}_{18}$ but higher $\mathrm{C}_{15}$ and $\mathrm{C}_{17}$ was obtained under high $\mathrm{H}_{2}$ pressure. The ratio of $\mathrm{DeCO}_{\mathrm{x}} / \mathrm{HDO}$ increased from 3.3 to 13 when the $\mathrm{H}_{2}$ pressure increased from 20 to 30 bar. This trend agrees with previous reports indicating that higher $\mathrm{H}_{2}$ partial pressure suppresses the formation of aromatic hydrocarbons, hence increasing the selectivity of n-alkanes during deoxygenation process of vegetable oil model compounds [35]. Moreover, as shown in Figure 4, light hydrocarbons $\left(\mathrm{C}_{8}-\mathrm{C}_{14}\right)$ concentrations in the final product are reduced under high $\mathrm{H}_{2}$ pressure, indicating that higher $\mathrm{H}_{2}$ pressure could inhibit the cracking of $\mathrm{C}-\mathrm{C}$ bonds in the deoxygenation process.

\subsubsection{Effect of LHSV}

Liquid hourly space velocity (LHSV) is an important parameter for regulating catalyst effectiveness. LHSV refers to the ratio of the feed flow rate to the volume of the packed catalyst [36]. A clear trend is observed in Figure 6 indicating that the deoxygenation of palm oil in terms of the TG conversion is favoured at low space velocities. This is actually expected, since the lower the space velocity, higher the reactants-catalyst contact time, favouring complete reaction cycles. The effect of LHSV on the product distribution is illustrated in Figure 6. At low LHSV the production of light hydrocarbon compounds $\left(C_{8}-C_{14}\right)$ is not favoured, whereas the production of $C_{15}$ and $C_{17}$ was greatly enhanced. At LHSV of $1.5 \mathrm{~h}^{-1}, \mathrm{DeCO}_{\mathrm{x}} \%$ possesses the highest value, i.e., around $75 \%$, or nearly 10 times higher than that of HDO. When the LHSV increased from 2.0 to 3.0, the DeCO $\%$ gradually decreased but the $\mathrm{HDO} \%$ remained almost unchanged (Figure 7). This is an important partial conclusion suggesting that the $\mathrm{HDO}$ route is barely affected by the space velocity while there was a negative impact on the $\mathrm{DeCO}_{\mathrm{x}}$ route when the space velocity was increased. 


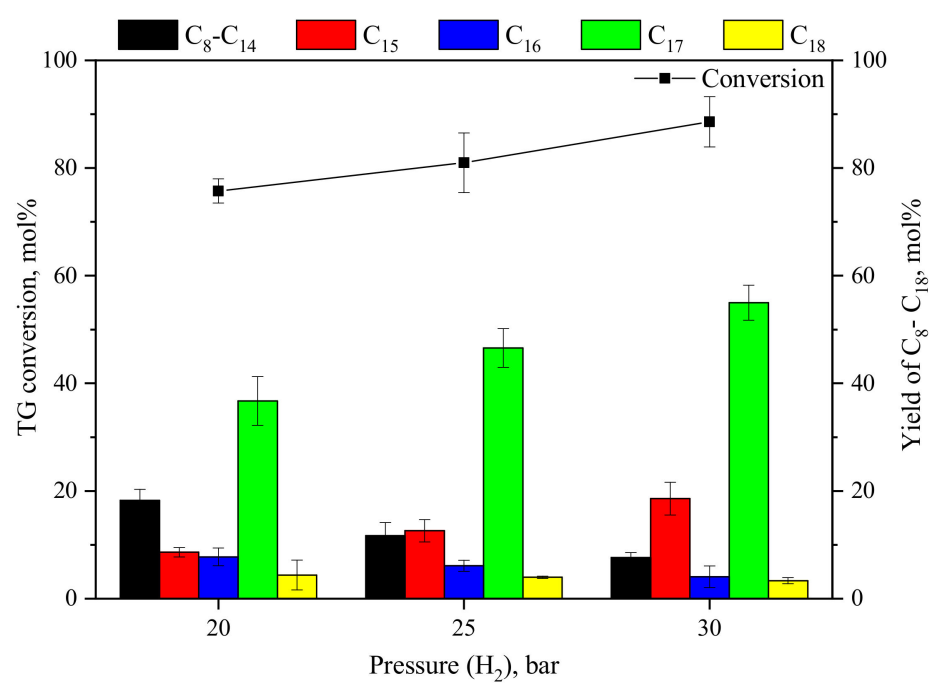

Figure 4. Conversion of triglycerides and yield of $\mathrm{C}_{8}-\mathrm{C}_{18}$ products under different $\mathrm{H}_{2}$ pressures.

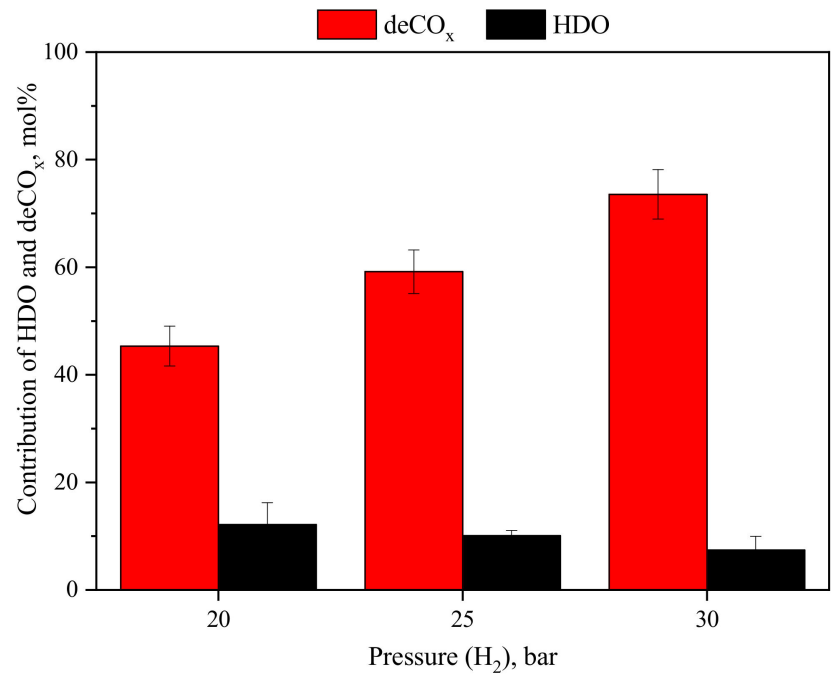

Figure 5. Contribution of $\mathrm{HDO}$ and $\mathrm{DeCO}_{x}$ under different $\mathrm{H}_{2}$ pressure.

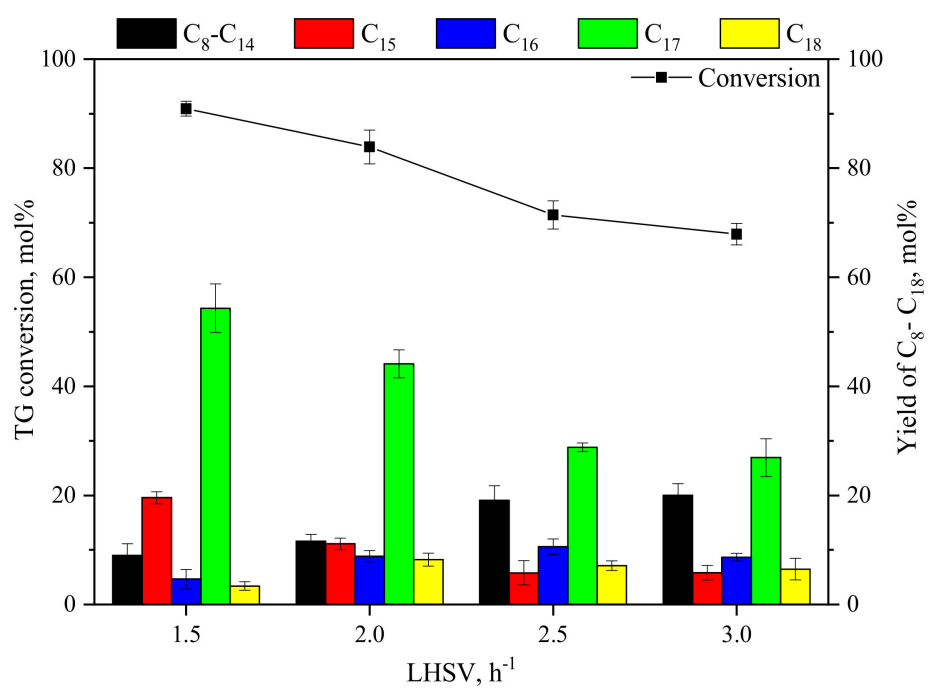

Figure 6. Conversion of triglycerides and yield of $C_{8}-C_{18}$ products under different LHSV. 


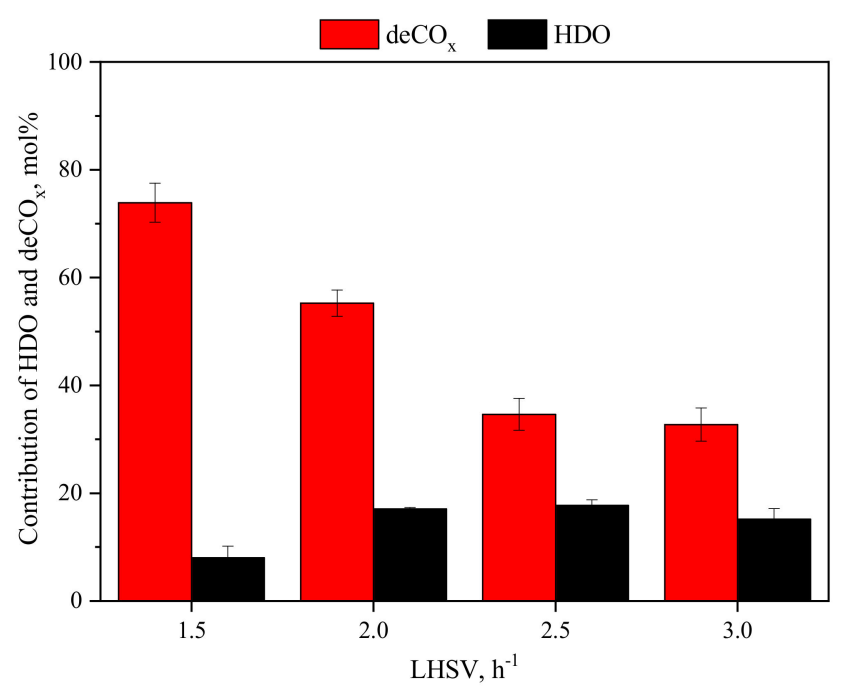

Figure 7. Contribution of $\mathrm{HDO}$ and $\mathrm{DeCO}_{\mathrm{x}}$ under different LHSV.

\subsubsection{Effect of Catalysts}

In order to validate the positive impact of $\mathrm{N}$ as dopant, a reference $\mathrm{Pt} / \mathrm{AC}$ catalyst was tested under the optimised reaction conditions: $\mathrm{T}=300^{\circ} \mathrm{C}, \mathrm{P}\left(\mathrm{H}_{2}\right)=30$ bar, $\mathrm{LHSV}=1.5 \mathrm{~h}^{-1}$ and $\mathrm{H}_{2} / \mathrm{oil}$ ratio $=1000 \mathrm{~cm}^{3} / \mathrm{cm}^{3}$. The conversion of triglycerides (TG) and the yield of $\mathrm{C}_{8}-\mathrm{C}_{18} \mathrm{n}$-alkanes in palm oil deoxygenation process over $\mathrm{Pt} / \mathrm{N}-\mathrm{AC}$ and $\mathrm{Pt} / \mathrm{AC}$ are depicted in Figure 8. Clearly, the conversion of TG was improved over the NC-supported catalyst compared to the AC-supported catalyst. Specifically, the conversion of TG was more than $90 \%$ over $\mathrm{Pt} / \mathrm{N}-\mathrm{AC}$ catalyst, while the $\mathrm{N}$-free catalyst barely reached $76 \%$ of overall conversion.

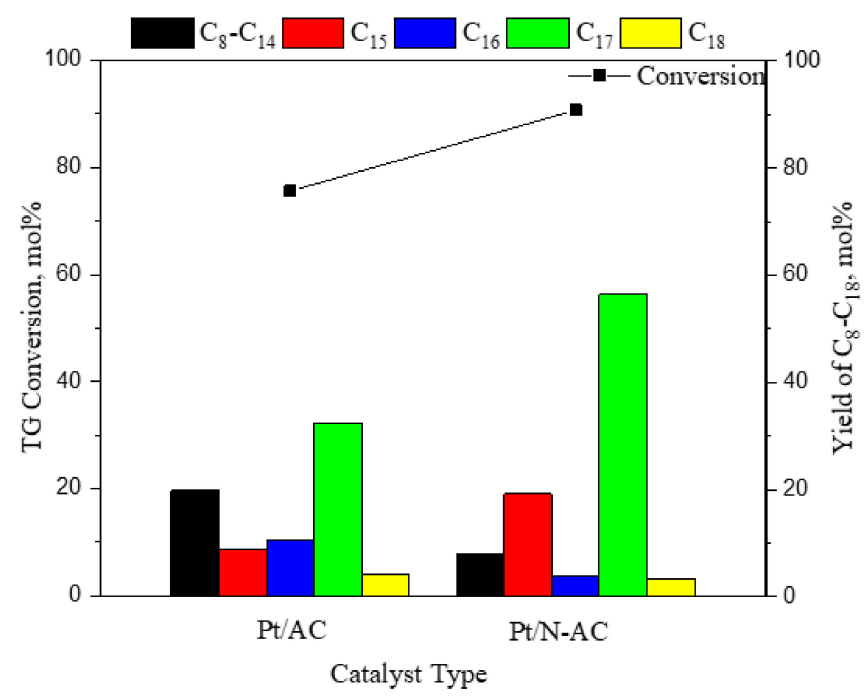

Figure 8. Conversion of triglycerides and yield of $\mathrm{C}_{8}-\mathrm{C}_{18}$ products over $\mathrm{Pt} / \mathrm{AC}$ and $\mathrm{Pt} / \mathrm{N}-\mathrm{AC}$ catalysts.

Very interesting trends in terms of selectivity are also observed in Figure 8. For instance, the lower yield of light hydrocarbon compounds $\left(\mathrm{C}_{8}-\mathrm{C}_{14}\right)$ produced from $\mathrm{Pt} / \mathrm{N}-\mathrm{AC}$ catalytic system compared to that of the $\mathrm{N}$-free catalyst indicates that the addition of $\mathrm{N}$ in the support suppresses the catalytic cracking of $C-C$ bonds, resulting in higher selectivity towards long chain n-alkanes $\left(C_{15}-C_{18}\right)$. Another significant different between the compared catalysts is marked preference of $\mathrm{Pt} / \mathrm{N}-\mathrm{AC}$ to favour the $\mathrm{DeCO}_{\mathrm{x}}$ route compared to the $\mathrm{Pt} / \mathrm{AC}$ catalyst. In fact, in both catalysts $\mathrm{DeCO}_{\mathrm{x}}$ is favoured over HDO under the studied reaction conditions but it is clear that the presence of $\mathrm{N}$ significantly favours $\mathrm{DeCO}_{\mathrm{x}}$ (Figure 9). This is a remarkable result from the process and catalysts design point of view since we 
can potentially control the selectivity by doping our carbon support with nitrogen. Figure 10 depicts the preferential interaction of carbonyl groups with $\mathrm{N}$-doped carbons, which seems to control the catalytic upgrading of palm oil over $\mathrm{Pt} / \mathrm{N}-\mathrm{AC}$ catalyst. Indeed, the presence of nitrogen alters the electronic density as well as the acid/base properties of carbon affecting the overall reactivity. As reported previously, the higher activity of $\mathrm{Pt} / \mathrm{N}-\mathrm{AC}$ results from the positive role of $\mathrm{N}$, which could help to stabilise metal particles and prevent the re-oxidation of metallic particles [27,37]. Also, nitrogen sites incorporated in the carbon network are envisaged as electron-rich sites where molecules can react. This also explains the higher selectivity for $\mathrm{DeCO}_{\mathrm{x}}$ when $\mathrm{N}$ is incorporated in the catalyst. Carbonyls are electrophilic groups which are prone to react with electronically rich species. Hence, we understand that $\mathrm{N}$-sites in our catalyst act as preferential sites to anchor carbonyl groups of the palm oil feedstock boosting the $\mathrm{DeCO}_{x}$ route over the $\mathrm{HDO}$ alternative. Irrespectively of the reaction pathways there is no doubt of the positive effect of $\mathrm{N}$ as dopant for the upgrading reaction.

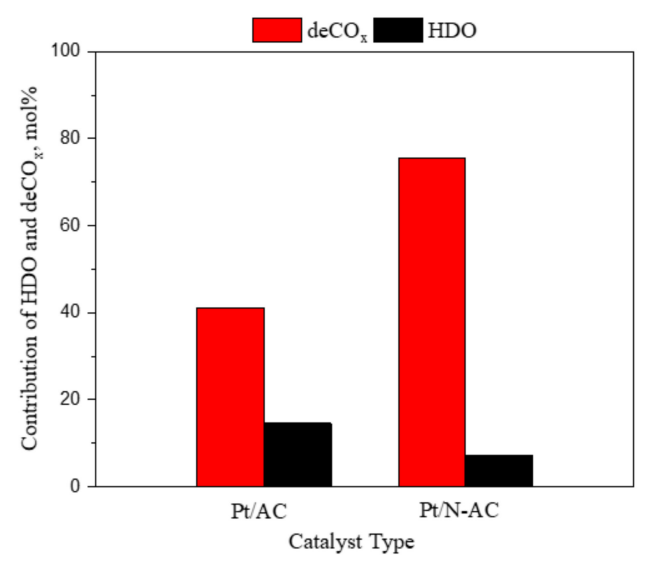

Figure 9. Contribution of $\mathrm{HDO}$ and $\mathrm{DeCO}_{\mathrm{x}}$ over $\mathrm{Pt} / \mathrm{AC}$ and $\mathrm{Pt} / \mathrm{N}-\mathrm{AC}$ catalysts.

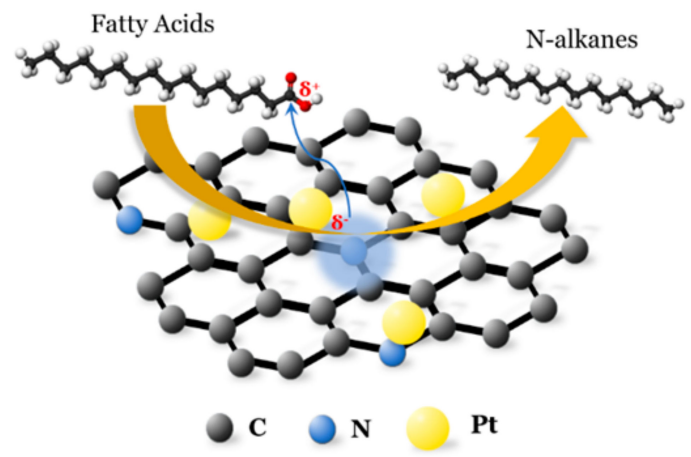

Figure 10. The scheme of catalytic deoxygenation of palm oil over Pt/N-AC catalyst.

A comparison of the catalytic performance of prepared $\mathrm{Pt} / \mathrm{AC}$ and $\mathrm{Pt} / \mathrm{N}-\mathrm{AC}$ catalyst in this work with those of others is presented in Table 2. The conversion of TG $(91 \%)$ in the present work is comparable to that obtained with other noble catalysts even though our experiments happened at lower temperature. Importantly, the yield of biodiesel production is much higher than those obtained over other noble catalysts. However, the conversion of TG in our reaction system is not as high as that reported over nonnoble catalysts, e.g., references $[3,38]$. However, it is worth emphasising that the DeCOx is the dominant reaction pathway in our reaction system, which is the preferable route from economic standpoint. 
Table 2. Green diesel production from palm oil in different catalytic reaction system.

\begin{tabular}{|c|c|c|c|c|c|c|c|c|c|c|}
\hline Catalyst & Reactant & Reactor & $\mathrm{T}\left({ }^{\circ} \mathrm{C}\right)$ & P of $\mathrm{H}_{2}$ (bar) & LHSV $\left(h^{-1}\right)$ & $\begin{array}{c}\mathrm{H}_{2} / \text { oil Ratio } \\
\left(\mathrm{cm}^{3} / \mathrm{cm}^{3}\right)\end{array}$ & $X(\%)$ & HDO $\%$, DeCOx $\%$ & $Y(\%)$ & Reference \\
\hline $1 \% \mathrm{Pt} / \mathrm{AC}$ & Refined palm olein & Fixed bed & 300 & 30 & 1.5 & 1000 & 76 & $\mathrm{HDO} \%=14.6 \% ; \mathrm{DeCO}_{\mathrm{x}}=41.2 \%$ & 76 & This study \\
\hline $1 \% \mathrm{Pt} / \mathrm{N}-\mathrm{C}$ & Refined palm olein & Fixed bed & 300 & 30 & 1.5 & 1000 & 91 & $\mathrm{HDO} \%=7.1 \% ; \mathrm{DeCO}_{x}=75.5 \%$ & 91 & This study \\
\hline $2 \% \mathrm{Pt} / \gamma-\mathrm{Al}_{2} \mathrm{O}_{3}$ & Refined palm olein ${ }^{1}$ & Trickle-bed & 330 & 50 & 1 & 1000 & 95 & $\mathrm{HDO} \approx 4 \%, \mathrm{DeCO}_{x} \approx 27 \%$ & 31 & [3] \\
\hline $5 \% \mathrm{Co} / \gamma-\mathrm{Al}_{2} \mathrm{O}_{3}$ & Refined palm olein & Trickle-bed & 330 & 50 & 1 & 1000 & 100 & $\mathrm{HDO} \approx 52 \%, \mathrm{DeCO}_{\mathrm{x}} \approx 35 \%$ & 89 & [3] \\
\hline $5 \% \mathrm{Pd} / \mathrm{C}$ & $\begin{array}{c}\text { Degummed Palm oil } \\
\text { (DPO) }^{2}\end{array}$ & Batch & 400 & 40 & $t=1 \mathrm{~h}$ & - & $\approx 80$ & - & 70 & [15] \\
\hline $2.45 \% \mathrm{Ni} 9.4 \% \mathrm{Mo} / \gamma-\mathrm{Al}_{2} \mathrm{O}_{3}$ & DPO & Batch & 400 & 40 & $t=0.5 \mathrm{~h}$ & - & $\approx 80$ & - & $\approx 50$ & [15] \\
\hline $4.95 \% \mathrm{Ni} 10.05 \% \mathrm{MoS}_{2} / \gamma-\mathrm{Al}_{2} \mathrm{O}_{3}$ & Palm olein oil $^{3}$ & Trickle-bed & 330 & 50 & 1 & 1000 & 100 & - & $\approx 98$ & {$[38]$} \\
\hline $4.95 \% \mathrm{Ni} 10.05 \% \mathrm{MoS}_{2} / \gamma-\mathrm{Al}_{2} \mathrm{O}_{3}$ & Refined kernel oil ${ }^{4}$ & Trickle-bed & 330 & 50 & 1 & 1000 & 100 & $\mathrm{HDO} \approx 60 \%, \mathrm{DeCO}_{\mathrm{x}} \approx 27 \%$ & $\approx 92$ & [38] \\
\hline
\end{tabular}

${ }^{1}$ Main components: $37.4 \%$ palmitic acid, $3.6 \%$ stearic acid, $45.8 \%$ oleic acid, $11.1 \%$ linoleic acid; ${ }^{2}$ Main components: 45.4 wt. $\%$ palmitic acid, 3.8 wt. $\%$ steric acid, 39 wt. $\%$ oleic acid, and 9.1 wt. $\%$ linoleic acid; ${ }^{3}$ Main components: $37.4 \%$ palmitic acid, $3.8 \%$ stearic acid, $45.8 \%$ oleic acid, $11.1 \%$ linoleic acid; ${ }^{4}$ Main components: $48.8 \%$ lauric acid, $17.3 \%$ myristic acid, $9.1 \%$ palmitic acid, $16.1 \%$ oleic acid. 


\subsection{Characterisation of Catalysts}

Further understanding of the behaviour observed for the N-doped catalyst is obtained by physiochemical characterisation of the sample. The textural properties of supports, AC and N-AC are shown in Table S2. The addition of N slightly decreased the surface area of carbon support. XPS of $\mathrm{Pt} 4 \mathrm{f}$ reveal that the addition of $\mathrm{N}$ shifts the binding energy of $\mathrm{Pt}$ indicating a modification of the Pt electronic environment as mentioned above (Figure S2). This is expected to improve the stability of catalysts as reported elsewhere [39]. TEM and XRD of reduced and spent catalyst were analysed in this study. As shown in Figure 11, Pt/N-AC catalyst revealed the uniform dispersion of small $\mathrm{Pt}$ particles (average particle size of $2.2 \mathrm{~nm}$ ) on the support. More importantly, the TEM image of spent $\mathrm{Pt} / \mathrm{N}-\mathrm{AC}$ remain almost unchanged compared to that of the fresh sample. No large agglomerates or obvious leaching were detected. Moreover, no difference can be found between the XRD pattern of reduced and spent Pt/N-AC catalysts (Figure S3). Overall, the TEM and XRD analyses indicate that the $\mathrm{Pt} / \mathrm{N}-\mathrm{AC}$ system is a robust and stable catalyst showing great potential for bio-Compounds deoxygenation reactions.

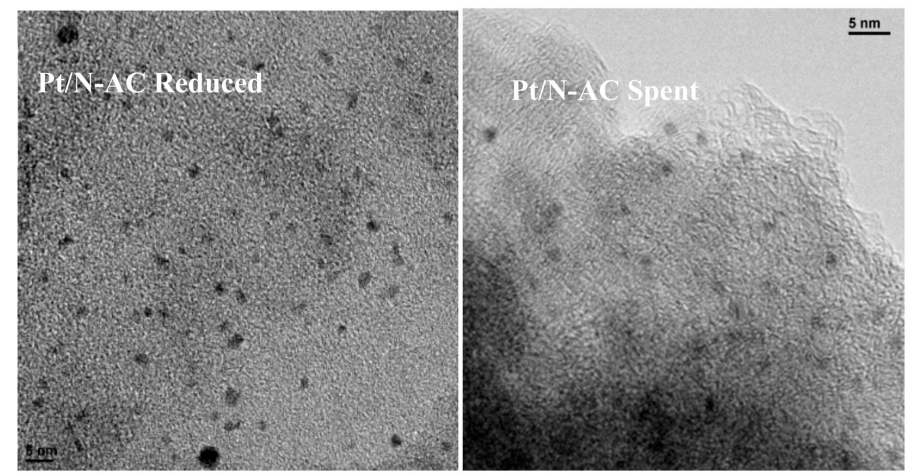

Figure 11. TEM of reduced and spent $\mathrm{Pt} / \mathrm{N}-\mathrm{AC}$ catalyst.

\section{Conclusions}

This work showcases the application of advanced N-doped Pt-carbon catalysts for the conversion palm oil into added value drop-in biofuels. In this particular case, the upgrade consists of oxygen removal to boost the net energy value of the end product. Two routes for oxygen removal are observed, i.e., $\mathrm{DeCO}_{\mathrm{x}}$ and $\mathrm{HDO}$, with the former being the preferential route in this study. The higher selectivity towards $\mathrm{DeCO}_{\mathrm{x}}$ products is due to the electronic modifications ascribed to $\mathrm{N}$ when it is incorporated in the carbon support network. This is a remarkable result from the process and catalysts design point of view, since we can potentially control not only the activity, but also the selectivity of the reaction by doping our carbon support with nitrogen.

The reaction conditions play a significant role in the process. For example, the overall conversion is favoured at higher pressures and low space velocities. As for the temperature, $300{ }^{\circ} \mathrm{C}$ seems to be an optimal choice. Again, the competition $\mathrm{HDO} / \mathrm{DeCO}_{\mathrm{x}}$ was also affected by the reaction conditions. $\mathrm{HDO}$ was favoured at higher temperatures, while higher pressures favoured $\mathrm{DeCO}_{\mathrm{x}}$. Interestingly, the space velocity barely affected the $\mathrm{HDO}$ route, but it did have a negative impact on the $\mathrm{DeCO}_{\mathrm{x}}$ pathway.

The $\mathrm{N}$-doped catalyst is superior to a reference $\mathrm{Pt} / \mathrm{AC}$ material and, very importantly, it is a very stable catalyst showing no signs of deactivation via sintering or carbon deposition during the reaction. Hence, this piece of work showcases an effective strategy to design highly active and stable catalysts for bio-compounds upgrades, and may inspire new opportunities in the area of low carbon, renewable fuel production. Attempts such as the effect of nitrogen source and amount of nitrogen in the catalyst's formula is worth exploration in the future to further improve the catalytic activity. Lessons learnt from the catalytic deoxygenation of refined vegetable oil to produce biodiesel could provide guidance for the application of inedible oil and waste cooking oil. Biodiesel production from inedible oil and waste cooking oil could alleviate the food vs. fuel debate, but there is still a long way to go. 
Supplementary Materials: The following are available online at http://www.mdpi.com/1996-1073/13/1/132/s1, Figure S1: Representative GC/MS chromatogram; Figure S2: XPS Pt 4f spectra for Pt-based catalysts after reduction treatment; Figure S3: XRD of activated and spent Pt/N-AC catalyst; Table S1. Composition of C8-C18 liquid products; Table S2: Textural properties of the supports.

Author Contributions: Conceptualization, T.R.R., S.G. and M.A.G.; methodology, L.P.-P., K.P., N.D.C.; software, W.J., M.M.P.-B., J.J.V.-P.; validation, W.J., A.S.-E. and L.P.-P.; formal analysis, J.J.V.-P., W.J., K.P., N.D.C.; investigation, W.J. resources, T.R.R., M.G., A.S.-E.; data curation, W.J., L.P.-P., M.M.P.-B.; writing-original draft preparation, W.J., T.R.R., M.A.G., L.P.-P.; writing-review and editing, A.S.-E., T.R.R.; visualization, M.G.; supervision, T.R.R., M.A.G., S.G.; project administration, T.R.R.; funding acquisition, S.G., T.R.R., M.A.G., A.S.-E. All authors have read and agreed to the published version of the manuscript.

Funding: This research was funded by the Department of Chemical and Process Engineering of the University of Surrey and the EPSRC grants EP/J020184/2 and EP/R512904/1 as well as the Royal Society Research Grant RSGR1180353. Authors would also like to acknowledge the Ministerio de Economía, Industrial Competitividad of Spain (Project MAT2016-80285-P) and the Chinese Scholarship Council (CSC). L.P.-P. also thanks Comunitat Valenciana for her postdoctoral fellow APOSTD2017. K.P. is grateful for the support of the Hellenic Foundation for Research and Innovation (HFRI) and the General Secretariat for Research and Technology (GSRT), under the HFRI PhD Fellowship grant (GA. No. 359). The APC was funded by University of Surrey.

Acknowledgments: Financial support for this work was provided by the Department of Chemical and Process Engineering of the University of Surrey and the EPSRC grants EP/J020184/2 and EP/R512904/1 as well as the Royal Society Research Grant RSGR1180353. Authors would also like to acknowledge the Ministerio de Economía, Industrial Competitividad of Spain (Project MAT2016-80285-P) and the Chinese Scholarship Council (CSC). L.P.-P. also thanks Comunitat Valenciana for her postdoctoral fellow APOSTD2017. K.P. is grateful for the support of the Hellenic Foundation for Research and Innovation (HFRI) and the General Secretariat for Research and Technology (GSRT), under the HFRI PhD Fellowship grant (GA. No. 359).

Conflicts of Interest: The authors declare no conflict of interest.

\section{References}

1. WBA Global Bioenergy Statistics 2018. Available online: https://worldbioenergy.org/ (accessed on 7 September 2019).

2. $\mathrm{Fu}, \mathrm{J} . ; \mathrm{Lu}, \mathrm{X}$; Savage, P.E. Hydrothermal decarboxylation and hydrogenation of fatty acids over $\mathrm{Pt} / \mathrm{C}$. ChemSusChem 2011, 4, 481-486. [CrossRef] [PubMed]

3. Srifa, A.; Faungnawakij, K.; Itthibenchapong, V.; Assabumrungrat, S. Roles of monometallic catalysts in hydrodeoxygenation of palm oil to green diesel. Chem. Eng. J. 2015, 278, 249-258. [CrossRef]

4. Ramya, G.; Sudhakar, R.; Joice, J.A.I.; Ramakrishnan, R.; Sivakumar, T. Liquid hydrocarbon fuels from jatropha oil through catalytic cracking technology using AlMCM-41/ZSM-5 composite catalysts. Appl. Catal. A Gen. 2012, 433, 170-178. [CrossRef]

5. Kubička, D.; Horáček, J.; Setnička, M.; Bulanek, R.; Zukal, A.; Kubičková, I. Effect of support-active phase interactions on the catalyst activity and selectivity in deoxygenation of triglycerides. Appl. Catal. B Environ. 2014, 145, 101-107. [CrossRef]

6. Murzin, D.Y.; Kubickova, I.; Snåre, M.; Mäki-Arvela, P.; Myllyoja, J. Method for the Manufacture of Hydrocarbons; Patent and Trademark Office: Washington, DC, USA, 2009.

7. Ochoa-Hernández, C.; Yang, Y.; Pizarro, P.; Víctor, A.; Coronado, J.M.; Serrano, D.P. Hydrocarbons production through hydrotreating of methyl esters over Ni and Co supported on SBA-15 and Al-SBA-15. Catal. Today 2013, 210, 81-88. [CrossRef]

8. Srifa, A.; Viriya-empikul, N.; Assabumrungrat, S.; Faungnawakij, K. Catalytic behaviors of $\mathrm{Ni} / \gamma-\mathrm{Al}_{2} \mathrm{O}_{3}$ and $\mathrm{Co} / \gamma-\mathrm{Al}_{2} \mathrm{O}_{3}$ during the hydrodeoxygenation of palm oil. Catal. Sci. Technol. 2015, 5, 3693-3705. [CrossRef]

9. Hollak, S. Catalytic Deoxygenation of Fatty Acids and Triglycerides for Production of Fuels and Chemicals. Ph.D. Thesis, Utrecht University, Utrecht, The Netherlands, 2014.

10. Peng, B.; Zhao, C.; Kasakov, S.; Foraita, S.; Lercher, J.A. Manipulating catalytic pathways: Deoxygenation of palmitic acid on multifunctional catalysts. Chem. Eur. J. 2013, 19, 4732-4741. [CrossRef]

11. Santillan-Jimenez, E.; Crocker, M. Catalytic deoxygenation of fatty acids and their derivatives to hydrocarbon fuels via decarboxylation/decarbonylation. J. Chem. Technol. Biotechnol. 2012, 87, 1041-1050. [CrossRef]

12. Immer, J.G.; Lamb, H.H. Fed-batch catalytic deoxygenation of free fatty acids. Energy Fuels 2010, 24, 5291-5299. [CrossRef]

13. Bertram, S. Heptadecaan: De wering van selenium op stearinzuur. Chem. Weekbl. 1936, 1, 457-459. 
14. Snåre, M.; Kubickova, I.; Mäki-Arvela, P.; Eränen, K.; Murzin, D.Y. Heterogeneous catalytic deoxygenation of stearic acid for production of biodiesel. Ind. Eng. Chem. Res. 2006, 45, 5708-5715. [CrossRef]

15. Kiatkittipong, W.; Phimsen, S.; Kiatkittipong, K.; Wongsakulphasatch, S.; Laosiripojana, N.; Assabumrungrat, S. Diesel-like hydrocarbon production from hydroprocessing of relevant refining palm oil. Fuel Process. Technol. 2013, 116, 16-26. [CrossRef]

16. Chen, H.; Zhang, X.; Zhang, J.; Wang, Q. Tuning the decarboxylation selectivity for deoxygenation of vegetable oil over Pt-Ni bimetal catalysts via surface engineering. Catal. Sci. Technol. 2018, 8, 1126-1133. [CrossRef]

17. Yang, L.; Carreon, M.A. Deoxygenation of palmitic and lauric acids over Pt/ZIF-67 membrane/zeolite 5A bead catalysts. ACS Appl. Mater. Interfaces 2017, 9, 31993-32000. [CrossRef] [PubMed]

18. Na, J.-G.; Yi, B.E.; Han, J.K.; Oh, Y.-K.; Park, J.-H.; Jung, T.S.; Han, S.S.; Yoon, H.C.; Kim, J.-N.; Lee, H. Deoxygenation of microalgal oil into hydrocarbon with precious metal catalysts: Optimization of reaction conditions and supports. Energy 2012, 47, 25-30. [CrossRef]

19. Alharbi, K.; Kozhevnikova, E.; Kozhevnikov, I. Hydrogenation of ketones over bifunctional Pt-heteropoly acid catalyst in the gas phase. Appl. Catal. A Gen. 2015, 504, 457-462. [CrossRef]

20. Hengsawad, T.; Jindarat, T.; Resasco, D.E.; Jongpatiwut, S. Synergistic effect of oxygen vacancies and highly dispersed $\mathrm{Pd}$ nanoparticles over $\mathrm{Pd}$-loaded $\mathrm{TiO}_{2}$ prepared by a single-step sol-gel process for deoxygenation of triglycerides. Appl. Catal. A Gen. 2018, 566, 74-86. [CrossRef]

21. Grosso-Giordano, N.A.; Eaton, T.R.; Bo, Z.; Yacob, S.; Yang, C.-C.; Notestein, J.M. Silica support modifications to enhance Pd-catalyzed deoxygenation of stearic acid. Appl. Catal. B Environ. 2016, 192, 93-100. [CrossRef]

22. Morgan, T.; Grubb, D.; Santillan-Jimenez, E.; Crocker, M. Conversion of triglycerides to hydrocarbons over supported metal catalysts. Top. Catal. 2010, 53, 820-829. [CrossRef]

23. Liu, X.; Xu, L.; Xu, G.; Jia, W.; Ma, Y.; Zhang, Y. Selective hydrodeoxygenation of lignin-derived phenols to cyclohexanols or cyclohexanes over magnetic CoNx@ NC catalysts under mild conditions. ACS Catal. 2016, 6, 7611-7620. [CrossRef]

24. Jiang, L.; Zhou, P.; Liao, C.; Zhang, Z.; Jin, S. Cobalt Nanoparticles Supported on Nitrogen-Doped Carbon: An Effective Non-Noble Metal Catalyst for the Upgrade of Biofuels. ChemSusChem 2018, 11, 959-964. [CrossRef] [PubMed]

25. Wang, G.H.; Cao, Z.; Gu, D.; Pfänder, N.; Swertz, A.C.; Spliethoff, B.; Bongard, H.J.; Weidenthaler, C.; Schmidt, W.; Rinaldi, R. Nitrogen-Doped Ordered Mesoporous Carbon Supported Bimetallic PtCo Nanoparticles for Upgrading of Biophenolics. Angew. Chem. Int. Ed. 2016, 55, 8850-8855. [CrossRef] [PubMed]

26. Fu, T.; Wang, M.; Cai, W.; Cui, Y.; Gao, F.; Peng, L.; Chen, W.; Ding, W. Acid-resistant catalysis without use of noble metals: Carbon nitride with underlying nickel. ACS Catal. 2014, 4, 2536-2543. [CrossRef]

27. Nie, R.; Yang, H.; Zhang, H.; Yu, X.; Lu, X.; Zhou, D.; Xia, Q. Mild-temperature hydrodeoxygenation of vanillin over porous nitrogen-doped carbon black supported nickel nanoparticles. Green Chem. 2017, 19, 3126-3134. [CrossRef]

28. Li, J.; Zhang, J.; Wang, S.; Xu, G.; Wang, H.; Vlachos, D.G. Chemoselective Hydrodeoxygenation of Carboxylic Acids to Hydrocarbons over Nitrogen-Doped Carbon-Alumina Hybrid Supported Iron Catalysts. ACS Catal. 2019, 9, 1564-1577. [CrossRef]

29. Mäki-Arvela, P.; Rozmysłowicz, B.; Lestari, S.; Simakova, O.; Eränen, K.; Salmi, T.; Murzin, D.Y. Catalytic deoxygenation of tall oil fatty acid over palladium supported on mesoporous carbon. Energy Fuels 2011, 25, 2815-2825. [CrossRef]

30. Lestari, S.; Mäki-Arvela, P.; Beltramini, J.; Lu, G.M.; Murzin, D.Y. Transforming triglycerides and fatty acids into biofuels. ChemSusChem 2009, 2, 1109-1119. [CrossRef]

31. Hermida, L.; Abdullah, A.Z.; Mohamed, A.R. Deoxygenation of fatty acid to produce diesel-like hydrocarbons: A review of process conditions, reaction kinetics and mechanism. Renew. Sustain. Energy Rev. 2015, 42, 1223-1233. [CrossRef]

32. Hellinger, M.; Carvalho, H.W.P.D.; Baier, S.; Gharnati, L.; Grunwaldt, J.D. Solvent Influence on the Hydrodeoxygenation of Guaiacol over $\mathrm{Pt} / \mathrm{SiO}_{2}$ and $\mathrm{Pt} / \mathrm{H}-\mathrm{MFI} 90$ Catalysts. Chem. Ing. Tech. 2015, 87, 1771-1780. [CrossRef] 
33. Pattanaik, B.P.; Misra, R.D. Effect of reaction pathway and operating parameters on the deoxygenation of vegetable oils to produce diesel range hydrocarbon fuels: A review. Renew. Sustain. Energy Rev. 2017, 73, 545-557. [CrossRef]

34. Chen, N.; Gong, S.; Shirai, H.; Watanabe, T.; Qian, E.W. Effects of Si/Al ratio and Pt loading on Pt/SAPO-11 catalysts in hydroconversion of Jatropha oil. Appl. Catal. A Gen. 2013, 466, 105-115. [CrossRef]

35. Kubičková, I.; Snåre, M.; Eränen, K.; Mäki-Arvela, P.; Murzin, D.Y. Hydrocarbons for diesel fuel via decarboxylation of vegetable oils. Catal. Today 2005, 106, 197-200. [CrossRef]

36. Kaewmeesri, R.; Srifa, A.; Itthibenchapong, V.; Faungnawakij, K. Deoxygenation of waste chicken fats to green diesel over $\mathrm{Ni} / \mathrm{Al}_{2} \mathrm{O}_{3}$ : Effect of water and free fatty acid content. Energy Fuels 2015, 29, 833-840. [CrossRef]

37. Xu, X.; Li, Y.; Gong, Y.; Zhang, P.; Li, H.; Wang, Y. Synthesis of palladium nanoparticles supported on mesoporous N-doped carbon and their catalytic ability for biofuel upgrade. J. Am. Chem. Soc. 2012, 134, 16987-16990. [CrossRef] [PubMed]

38. Itthibenchapong, V.; Srifa, A.; Kaewmeesri, R.; Kidkhunthod, P.; Faungnawakij, K. Deoxygenation of palm kernel oil to jet fuel-like hydrocarbons using Ni-MoS $2 / \gamma-\mathrm{Al}_{2} \mathrm{O}_{3}$ catalysts. Energy Convers. Manag. 2017, 134, 188-196. [CrossRef]

39. Xia, W. Interactions between metal species and nitrogen-functionalized carbon nanotubes. Catal. Sci. Technol. 2016, 6, 630-644. [CrossRef]

(C) 2019 by the authors. Licensee MDPI, Basel, Switzerland. This article is an open access article distributed under the terms and conditions of the Creative Commons Attribution (CC BY) license (http://creativecommons.org/licenses/by/4.0/). 